\title{
Development of a Cost Model for Intermodal Transport in Spain
}

\author{
Jesús Muñuzuri, Rafael Grosso, Pablo Cortés and José Guadix \\ University of Seville, Organisation Engineering \\ Spain
}

\section{Introduction}

For several years, the promotion of intermodal transport has been a priority for the Spanish and European authorities (Cuerda et al., 2003; Conseil National des Transports [CNT], 2005) but the importance and the recent growth of rail transport in Spain is extremely small compared to road transport. This is more so in the case of small and medium-size companies shipping general (non-bulk) cargo, which almost exclusively use the road (Ministerio de Fomento, 2004). The establishment of a network of intermodal freight transport centres connected to the main railway lines and close to the main cities is viewed as an opportunity for the modal shift, and also the establishment of relevant intermodal corridors dedicated to specific freight purposes (ore, agricultural products), to be defined at a European level, should improve the overall figures. But nevertheless, there is the feeling in Spain that more attention should be given to general traffic issues, facing the needs of the great amount of small companies moving small amounts of freight, but with an enormous aggregate effect.

Thus the strategic objectives of our work lie within the rationalization of mobility and the improvement of intermodal accessibility. They concentrate on establishing the basis for a higher participation of small and medium-size companies in intermodal transport by analyzing the specific experiences of an individual transport company, based in the city of Seville, seeking an enhancement of the modal shift within its logistic operations.

This work is organized as follows: In section 2 we describe the role of intermodal transport in the supply chain. In Section 3 we list the actors involved in all phases of intermodal transport to then show the decision-making model for each one of these actors. In Section 4 we apply this model to the case of a transport company based in the South of Spain, describing all the shipment and cost data. Finally, in section 6 we explain our conclusions drawn from the decision making model in general and in particular for the case-study company, and analyze the effect of additional factors (other than cost) in the decisionmaking process with respect to intermodal transport.

\section{Intermodal transport and the supply chain}

The role of intermodal transport in supply chains is clearly described by Ramstedt and Woxenius (2006). According to them, 
- A supply chain focuses a product and extends back over the integrated chain of actors, activities and resources required for making it available at the place of consumption.

- A logistics chain focuses an item and extends from when the article number is created until it is dissolved (article consumed or becoming a part of another article).

- A transport chain focuses a consignment and extends over movement, physical handling and activities directly related to transport such as dispatch, reception, transport planning and control.

Thus, the transport chain is a relevant component of logistics chains, which in turn compose supply chains involving many different actors which can act as logistics service buyers or logistics service providers. For these three types of chains, it is essential, but complicated, to define the exact configuration and roles of the actors. Different actors involved in an intermodal transportation chain are:

- Ship-owner: the real owner of the ship. The owner may use the ship for his own benefit or may rent it for external use.

- Charterer: an individual or legal entity who hires or charters a ship for their own profit. For example, an operator who hires the use of a ship from the ship-owner is known as the charterer of that ship.

- Shipper: a person or company who entrusts his goods to a third party (which may become the charterer with regard to the sender) who will deliver them to their destination. In the example being used, when the transport agency contacts the shipping company, the transport agency becomes the sender in relation to the shipping company.

- Forwarding agent: an individual or legal entity responsible for coordinating the carriage of goods according to the client's needs. The forwarding agent contacts all companies providing services involved in the carriage. They may also act as the Customs Official. The intervention of the forwarding agent is quite useful in large operations. They are transport specialists who will closely monitor the selected operation and the costs incurred.

- Consignee: is an individual or legal entity acting in the name of the ship-owner, in terms of administrative and technical procedures, port activities, fees incurred by shipowner for docking and services provided while in the port terminal, etc... The consignee also carries out the procedures required for customs clearance, when importing or exporting is involved, and may also negotiate with stowing companies on behalf of the ship-owner.

- The stowing company is responsible for handling goods within the port during:

- Loading: reception, loading and stowing.

- Unloading: break bulk, unloading, delivery.

- Emptying and filling containers.

- Sorting goods.

- Horizontal movements to position goods in inspection areas.

All these different links in the transport chain can be managed by the shipping company itself, directly contacting operators and arranging transport and storage operations. However, and more so in the case of small and medium companies, this management requires an enormous effort, and the preferred option is often the subcontracting of different actors, or a single actor who manages the whole process. 


\section{Modelling the decision-making process}

The intermodal chain connects the origin and the destination of goods through a series of links, some of which are decision-nodes, that is, decisions have to be made in terms of how to proceed from them, or what option to choose in order to carry the freight to the next node. The stakeholders involved in the intermodal chains will therefore have to take a series of decisions regarding what intermodal operators will be involved in the delivery, taking into account factors like time, cost and route choice.

This is the type of decisions that was brought into the model. In any case, the transport modes considered were rail, vessel and road, excluding air transport due to its totally different characteristics, which cause it not to be a competitor for road transport in terms of general cargo. The possible intermodal operators to be considered were logistic operators, forwarders, the rail operator (Renfe), and the ship companies.

Different models have been formulated in the literature to optimise the efficiency of intermodal transport (Arnold et al., 2004 ; Ballis \& Golias, 2004 ; Barthel \& Woxenius, 2004 ; Li \& Tayur, 2005; Macharis \& Bontekoning, 2004). In this case, a cost model was derived in order to assess the effectiveness of intermodal transport in terms of costs. The objective was to represent all the possible options and alternatives that companies have when shipping or transporting a given delivery. Three different decision-making models were therefore built, one for each decision-making stakeholder in the intermodal chain:

- The shipper: generates and sends the goods, and is therefore in charge of deciding how and by what means those goods are going to be handled and transported.

- The forwarder: instead of organizing the delivery himself, the shipper can subcontract a forwarder to do it, thus passing the responsibility and the decision-making process to it. The forwarder acts as an intermediary, making all the necessary arrangements but not necessarily taking actual hold of the freight.

- The logistic operator: it can be subcontracted by either the shipper or the forwarder, and will then decide on the transport mode to use.

In each model, the different choice options for the corresponding stakeholder were linked.

\subsection{The shipper's decision making process}

The first decision (see Figue 1) that the shipper will have to take will depend on whether they have the appropriate fleet for the journey and the connections between the point of origin and destination. If they have the appropriate fleet available and they are able to transport the goods themselves by land, then they need to decide whether to do the job themselves or subcontract it. If the job requires other transportation modes, the only decision possible is to contract out the service. It is in the latter case that the concept of the intermodal transport chain is introduced.

The reasons for contracting out the service may be:

- $\quad$ Lack of means available to carry out the job themselves.

- Have means available, however do not wish to use them.

- Another transportation mode is necessary due to existing connections between the origin and destination points.

In all three cases, the shipper will have to decide which operator to contract and how. This decision will depend on existing connections between the point of origin and destination. Connection types: 
- Direct road connections between both points. In this case, an intermodal transport chain is not necessary since land carriage is the only transportation mode required.

- Rail connection: goods must be transported in part by rail. As a result the respective carriages will have their point of origin and destination in the corresponding rail terminals.

- $\quad$ Sea connection, in which part of the journey must be done by ship.

There will be different diagrams representing the operator's decision making process depending on the connection types between the points of origin and destination.

\section{ST DECISION MAKING PROCESS}

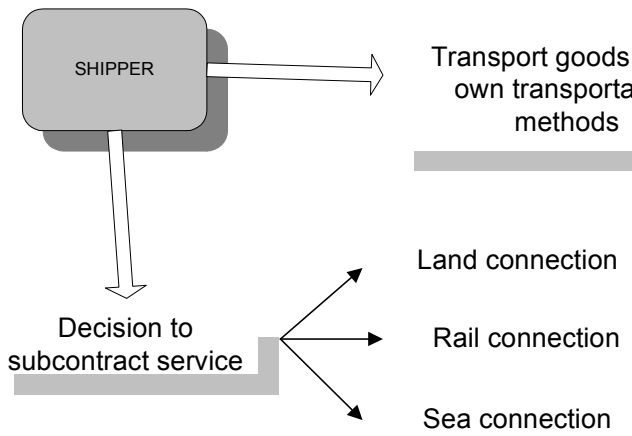

Fig. 1. Shipper's first decision making process

\subsubsection{Direct connection by road}

Land carriage is the only transportation mode required. In this case, the intermodal operators who may participate are:

- Transport company

- The forwarding agent

Since there are neither sea nor rail routes respectively, neither the shipping nor rail company will gain from providing land carriage and therefore will not provide their services to the shipper. In cases where rail and/or sea carriage are required, these operators will offer their transportation services even if it is only over a short distance. In this way the client receives a more comprehensive and better quality service.

The hypotheses involved are the following:

- The distance covered during the journey is less than $300 \mathrm{~km}$.

- The distance covered is greater than $300 \mathrm{~km}$ and the only transportation method available is by land.

Bearing these hypotheses in mind, the following diagram (Figure 2) may be followed: 


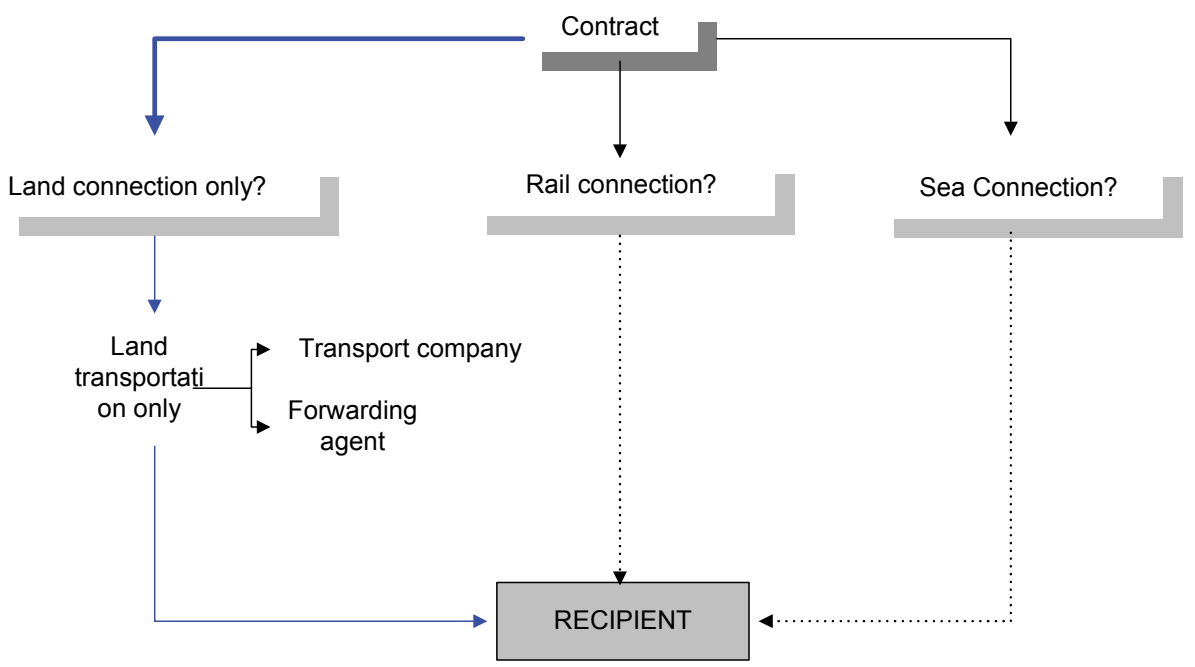

Fig. 2. Shipper's decision making process.

\subsubsection{Connection with rail carriage}

In this case, the rail company acts as a possible intermodal operator since a section of rail network is found along the established route. Two types of rail connection are possible (see Figure 3):

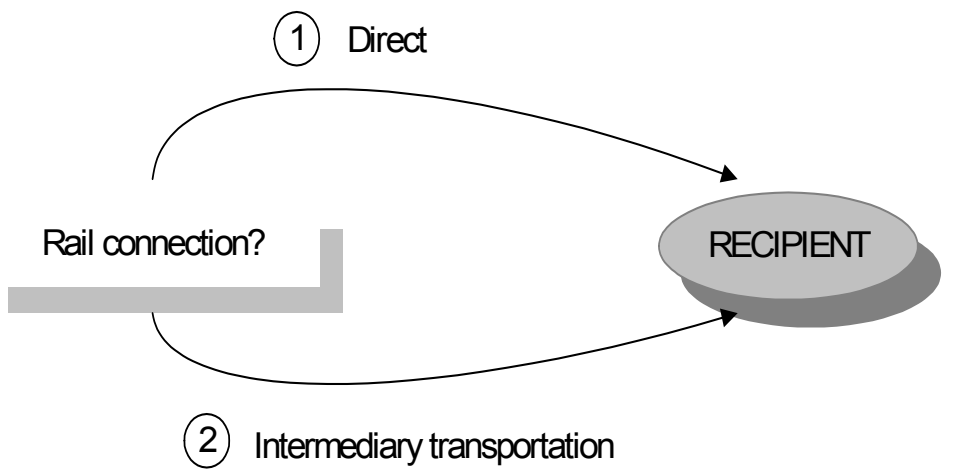

Fig. 3. Possible rail connections.

1. A direct rail connection means that the point of origin and destination are connected by one railway line. This may be a main line or a secondary one. Based on the hypothesis that it is the shipper who chooses the transportation mode and the route, the only operators who are able to participate are the railway company and the forwarding agent. This must be pointed out as the shipper may contact his usual transportation company and contract the service to them, even though the goods will not be transported by land. 
2. A non-direct rail connection means that an intermediary section of the journey will be made by land. The possible transportation routes may be: the first stage from the point of origin to the train departure terminal, from the train arrival terminal to the destination point or both.

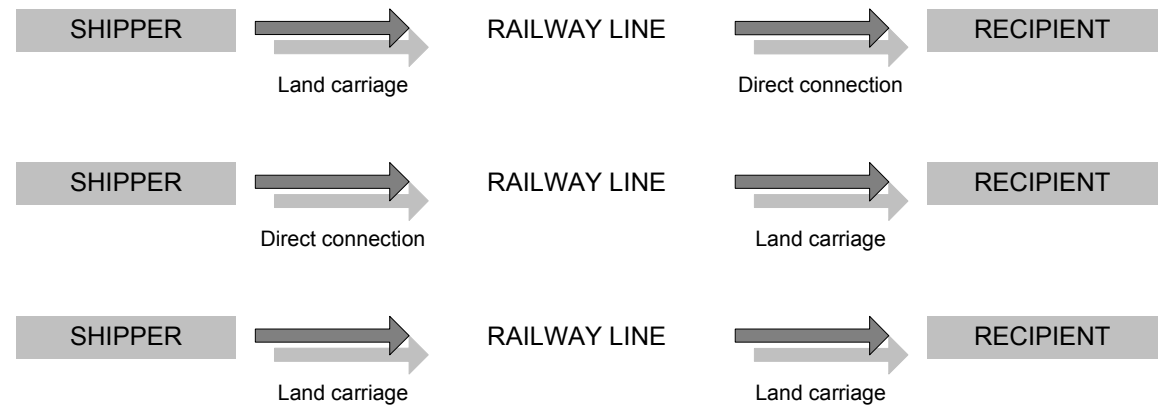

Fig. 4. Land transportation.

In the previous diagram (Figure 4) direct connection was used when the point of destination had some type of railway access, whether it is a secondary or a main line.

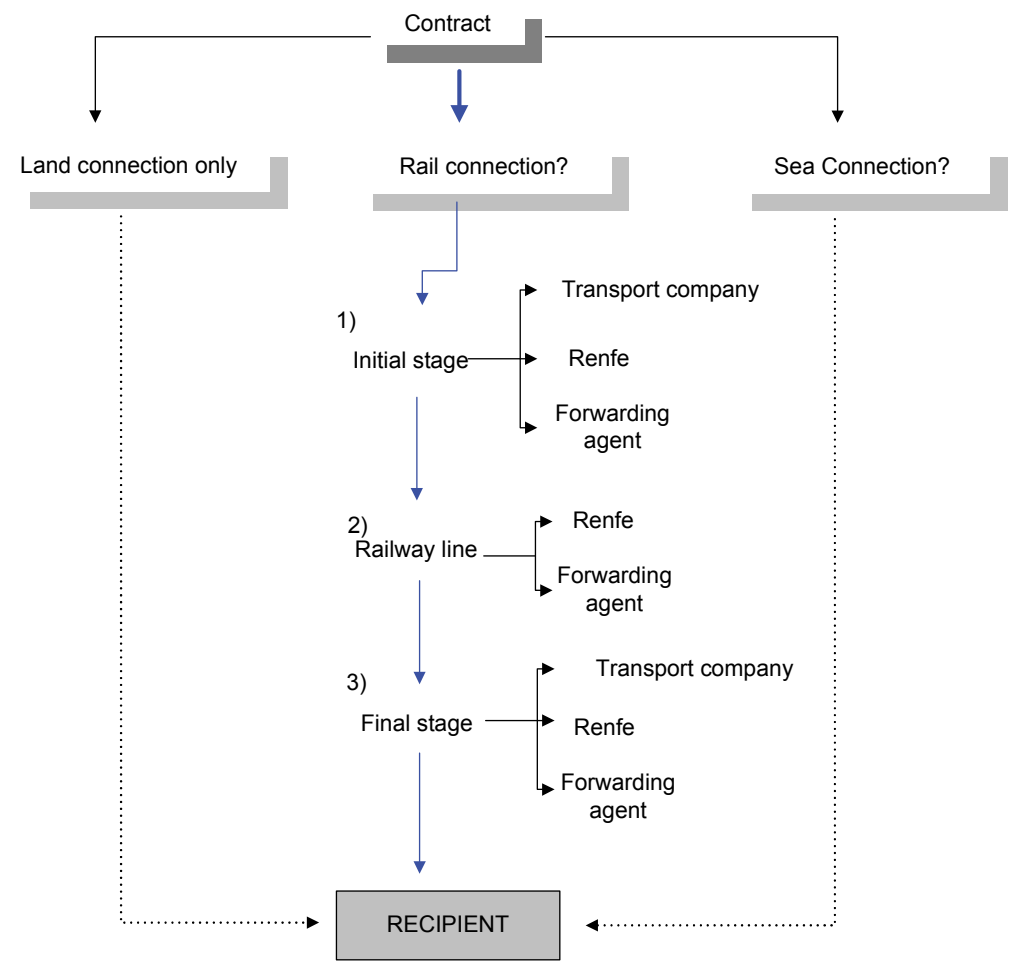

Fig. 5. Shipper's decision making process. 
In order to outline the shipper's decision making process, let us look at the most complicated scenario. This would occur when, in addition to rail carriage, two stages of the chain are to be completed by land, i.e., the first stage from the point of origin and the final stage to the point of destination.

The intermodal operators who may participate are:

- The transport company.

- The rail company.

- The forwarding agent.

Each of them may manage the entire route and act as the sole intermodal operator for the shipper (see Figure 5).

\subsubsection{Connection with sea carriage}

Up until now we have mentioned three operators, the transport company, the rail company and the forwarding agent. In cases of sea carriage, the shipping company acts as an intermodal sea operator. Three different scenarios may be identified depending on the established connections between the point of origin and destination (see Figure 6).

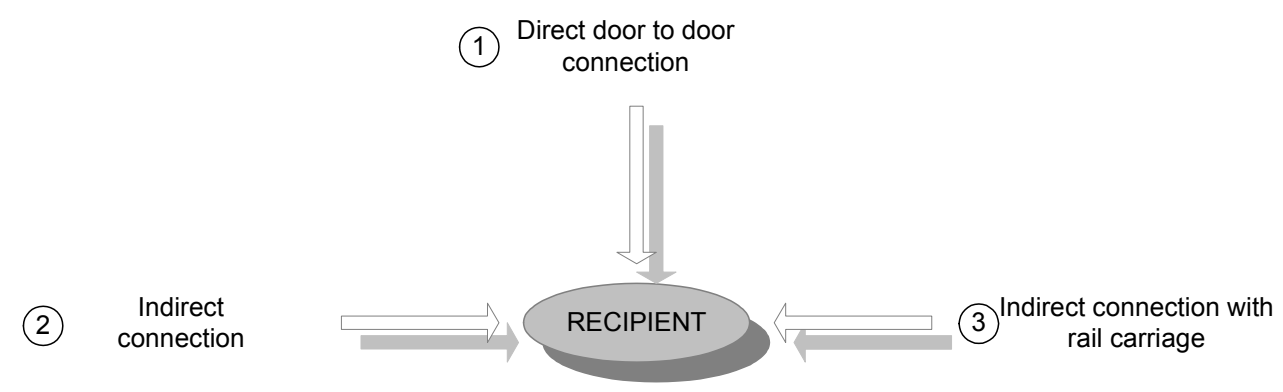

Fig. 6. Possible sea connections.

\subsubsection{Direct connection from port to port}

The shipper and the recipient are situated within the departing and arrival ports respectively. This means that the only land journeys to be made are due to the intermodal handling and moving of the load units within the port terminals. These movements are carried out by the ship's stevedores (personnel dedicated to carrying out this type of service) or by those in the port terminal. As a result, the transport company cannot act as a possible intermodal operator for this type of connection. The intermodal operators who may participate are:

- The forwarding agent

- The shipping company

\subsubsection{Indirect connection}

Indirect connection means that the intermodal route includes a stage to be completed by road, for example, outside the port terminal. This means that the origin and/ or destination point are not located within the port. As a result, transportation by land is required. In this case, in addition to the operators already mentioned, the transport company may also act as a possible intermodal operator. 


\subsubsection{Indirect connection with rail carriage}

There is a section of railway along the route by which the goods will be transported. Here we have the most complicated scenario since it involves three types of transportation modes: land, rail and sea.

If a section of the journey is to be completed by land, then the road transport company may once again act as an intermodal operator. Usually the shipper or docker contacts one intermodal operator only or two at the most. This does not mean that they cannot contact a different one for each section of the journey. However, this rarely happens and it would most probably be very a very laborious task for the shipper. If they decide to contact one intermodal operator only, this may be the:

- Transport company.

- Rail company.

- Shipping company.

- $\quad$ The forwarding agent.

As long as they are duly authorised, all operators are capable of managing the entire intermodal chain.

The following figure shows the decision making process:

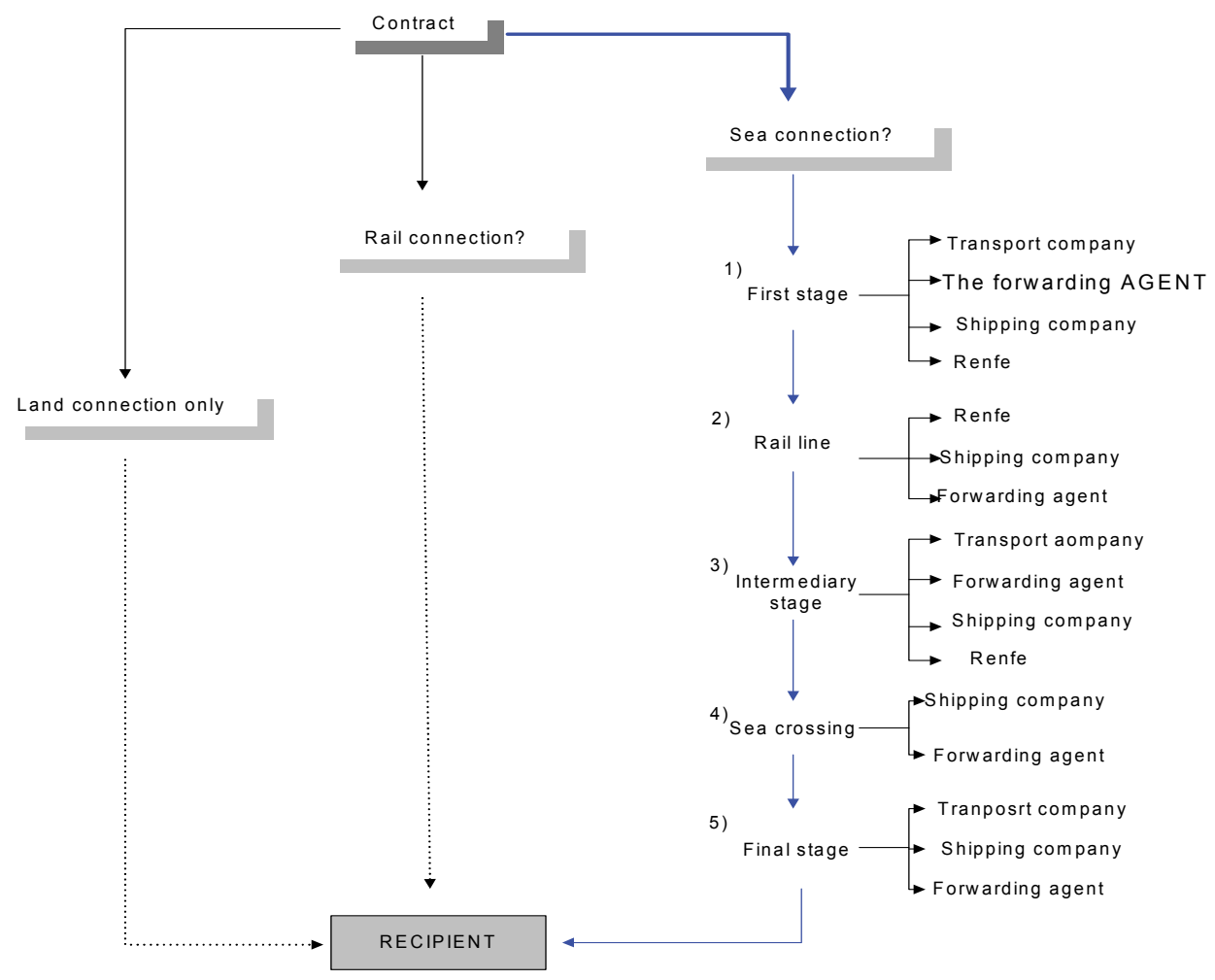

Fig. 7. Shipper's decision making process 
The last scenario represents the most extensive example of an intermodal chain since it includes three different transportation modes. We will therefore look at how this process develops in more detail.

- If the goods are to be transported via a route such as the one above, the shipper will normally assign management of the entire route to one operator only. The forwarding agent, the shipping company, the transport company and the rail company are all able to carry out this task. In Spain, the rail company with the greatest influence up until now is Renfe. In some cases, although not many, Renfe has provided the entire service, including management of sea carriage. In this study and for this reason, we will work under the hypothesis that Renfe does not provide the complete service in cases where sea carriage is necessary. As a result the number of operators is reduced to three.

- A more detailed study is required in cases where the shipper contracts the shipping company as the only intermodal operator. In general, the shipping company will manage all aspects of the process except for customs procedures which will be carried out by the forwarding agent or a customs official. The shipper will contract a customs official to carry out all necessary tasks. Alternatively, the shipping company may be responsible for contracting the customs official. In this case the shipping company will subcontract a customs official to perform all duties. Since the shipping company is not responsible for customs processes, it is normally the shipper who will contract the customs official.

- Once this decision has been made, the shipping company is responsible for contracting the shipping company to load a certain type of goods at the point of origin and transport it to the destination point. If the point of origin is inland and not a port, then the goods must be transported to the port. This may be done by land or by rail. In both cases the shipping company will have to subcontract the transport company for land carriage and the rail company for rail carriage. The latter may also provide land carriage.

- Once the goods are in the port and are ready for loading onto a pre-assigned vessel, they need to pass through customs before loading.

- As already mentioned, the client has two possibilities available to him. He may either contact the customs official directly or he may contact him through the shipping company. In both cases, a series of data included in the commercial invoice for the goods must be provided.

- Once the necessary documentation has been signed and dispatched, it should be delivered to the shipping company's premises within the point of origin. With this documentation the shipping company is now able to load the goods into the preassigned vessel.

Once the shipper in origin has paid the costs agreed with the shipping company, the shipping company should send the shipper a Bill of Lading $(\mathrm{B} / \mathrm{L})$ proving that the shipper is the owner of the goods.

- Once the docker has received this document, it is sent to the destination client or consignee who will need it to unload the goods at the destination port.

- The transit will take a specific amount of time. It will follow a specific route and may have several ports of call or transhipment ports before arriving at the destination port.

- When the goods arrive at the destination port, the client in origin should have paid the shipping company a series of costs already agreed in the commercial invoice. These costs will depend on the terms of sale agreed by the shipper or docker and the shipping company. It is at this point that the Incoterms come into effect. For example EXW, FAS, FCA, FOB, CFR, CPT, CIF, CIP, DAF, DES, DEQ, DDU, DDP. 
- When importing, in order to unload the goods, the destination client should have the documentation proving that he is the owner of the goods, i.e., the B/L. He should also reimburse the shipping company for any costs, according to the terms of sale set out in the contract drawn up between the two contracting parties. Depending on Incoterm, the docker should pay some of the costs or all of them (the recipient also pays). In this way the recipient of the goods is able to receive the goods in their factory.

- If the goods are to be delivered to a point inland after the destination port the transport company at the point of destination or the rail company comes into play again. The process may be carried out in the same way it was for the point of origin.

- At this point the recipient of the goods should contact the customs official or the forwarding agent so that they can perform the customs importation process. Alternatively they may contact the shipping company who will subcontract the service to a forwarding agent or a customs official.

- Once the customs process has been completed, the goods may be transported by land or rail. This will depend on what the recipient or shipper deems appropriate. Depending on their decision they will contact the transport company or Renfe.

- The shipping company may offer door to door service to the shipper or, as already mentioned, the door to door operation may carried out by a combination of both. Normally the shipping company is responsible for the complete door to door intermodal transportation. In this way the shipper receives a better service and problems are avoided.

Once the possible decisions have been looked at individually, we can see the entire shipper's decision making process in the following figure:

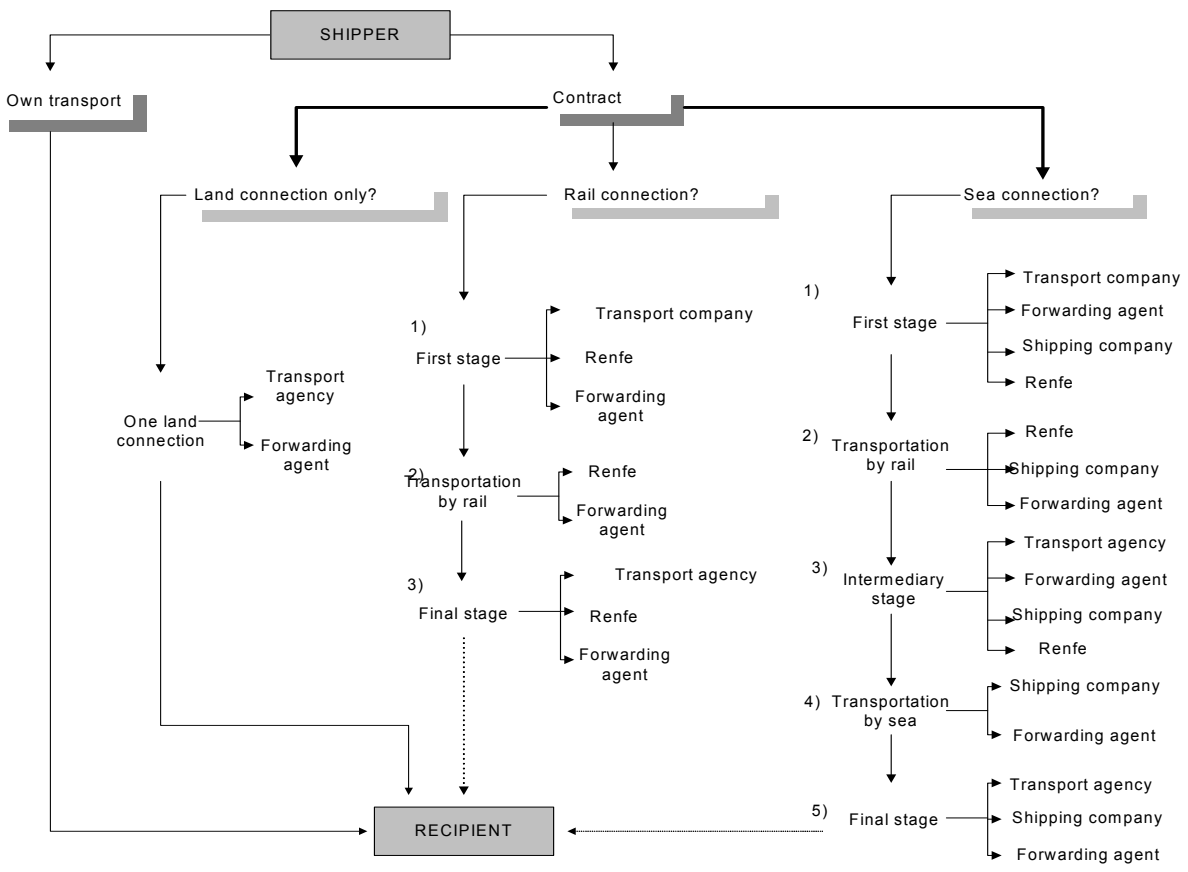

Fig. 8. Shipper's decision making process, depending on the intermodal chain used. 


\subsection{Forwarding agent's decision making process}

The forwarding agent organises and coordinates transportation. The forwarding operator chooses and contracts the transportation modes for the transportation of goods. The forwarding operator must control and coordinate goods during all of the transportation stages, whether this is by land, rail, sea or air.

In practice, the forwarding operator also takes care of transportation involving land carriage only and acts as a Transport Agency in such cases. However, if land carriage only is required, it is not common for a shipper to contact a forwarding agent if they have the option to contract the land transportation company directly. If this does occur, it may be due to the fact that the shipper is using this forwarding agent to transport other goods and decides to assign them this land carriage as well.

When the client contacts the forwarding agent, they look at the most appropriate itineraries and the different transportation modes available. The best solution in terms of costs, time and security is always selected.

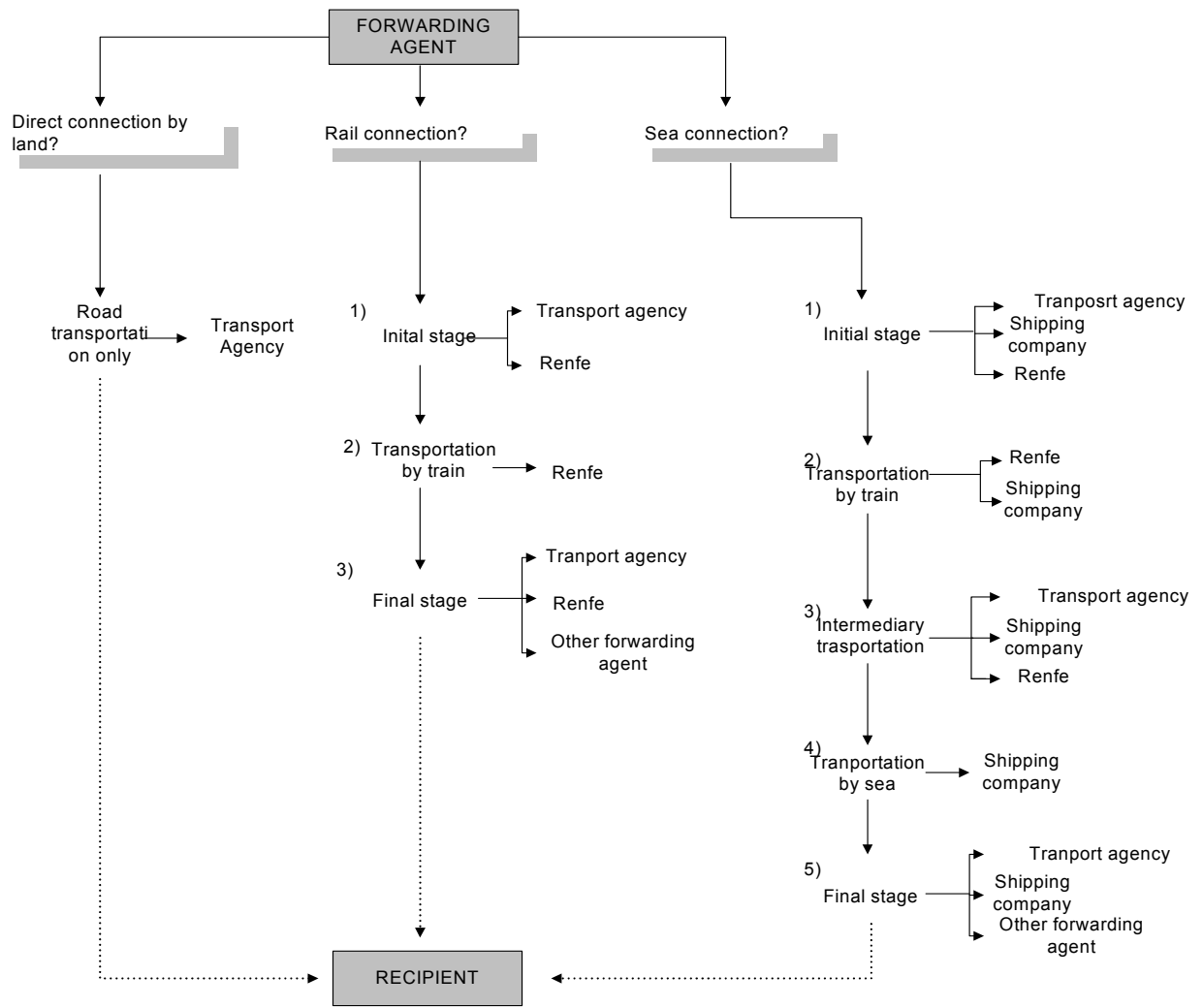

Fig. 9. Shipper's decision making process, according to the intermodal chain used.

There may be occasions when the forwarding agent has to subcontract the services of another forwarding agent to manage a certain part of the intermodal transit in origin or destination. This may be due to the fact that they do not have links with any other transport 
agencies in the area. In cases where agreements between forwarding agents are made, we refer to this as "collaboration between agents".

The forwarding agent's decision making process may be presented as follows (Figure 9):

Hypothesis used to complete the table:

- We have not considered the scenario where there is no door to door rail connection between the point of origin and destination, either on main or secondary lines.

- The forwarding agent does not collaborate with another forwarding agent in the initial nor intermediary stages, nor the rail nor sea carriage since all of the transportation means fall under its trading area.

- When goods are transported by sea, once they reach the destination port they are then transferred to the point of destination by land. In other words, there is no rail connection point between the destination port and the point of destination. This is not to say however that in reality there may be. This is simply a means of creating a table which is less complicated and easy to follow.

The shipper usually contacts the forwarding agent who will take care of the entire operation (land carriage and sea and rail carriage if required).

When the forwarding agent makes decisions regarding shipping he reaches an agreement with the shipping company so that they perform all procedures required by the type of cargo. At this point there are a number of possibilities. The shipping company regards the forwarding agent as a client or shipper and determined terms of sale are established between the two, according to the service offered by the shipping company:

- Sea carriage along with one or all other stages done by land, whether they be in origin or in destination and rail carriage if available.

- Sea carriage only.

- Sea and rail carriage (if available).

- Sea carriage and others.

When goods are being transported by sea it is important that they are cleared by customs so that they may be unloaded.

Regarding the customs clearance at the point of origin, the forwarding agent is responsible for carrying out the necessary customs processes and will act as a customs official. On some occasions the shipping company may take care of customs clearance. However, this is not common since it incurs an added expense for the forwarding agent. If the forwarding agent deals with this, costs will be centralised and reduced. If the forwarding agent carries out the customs clearance it will cost approximately 30 euros. In comparison, if this is done by the shipping company it would cost 35-40 euros. Centralising costs results in a more favourable quality-price relationship.

Customs clearance at the point of destination cannot be carried out by the forwarding agent at the point of origin. It is always done by the goods recipient. The recipient may contract another forwarding agent or a shipping company at the point of destination to take care of customs processes relevant to the destination.

Depending on the shipper's turnover, they may contract the transport agency or the shipping company to transport the goods by land. The shipping company subcontracts certain transport agencies and will normally have a fixed price agreement with them ensuring lower prices than those charged to a shipper or a forwarding agent (client). This is due to the fact that shippers or forwarding agents only require the services of the transport agency for a small amount of transportations while the shipping company will always require a huge amount of transportations per year. 
The shipping company is not always able to manage transportations. There are countries in which transportation services cannot be subcontracted because this service is not offered due to its lack of profitability.

As mentioned earlier, the forwarding agent may also act as a customs official. As soon as the goods arrive at the port terminal, whether it be at the point of origin or destination, they should pass through customs so that they can be unloaded and leave the port. If they fail to do so the goods will be stored in a warehouse until a new customs clearance is requested (see Figure 10).

\section{CUSTOMS CLEARANCE}

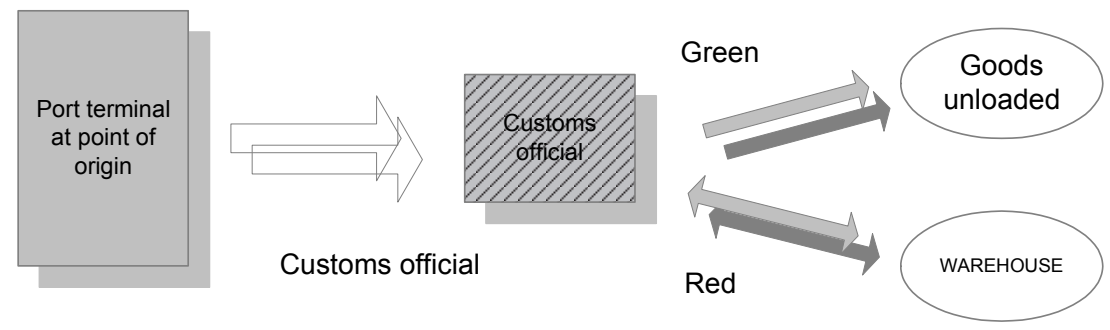

Fig. 10. Customs clearance process.

There are different types of customs clearance:

- Shipments within the European Community.

Shipments carried out in countries belonging to the European Economic Community. A customs document is required to transport goods by sea within the geographical area of the Economic Community.

The TL2, as it is referred to, is one single document, which once presented to and sealed in customs, should be delivered to the shipping company's premises within the port of loading. The shipping company arranges the unloading of the goods into the previously assigned vessel and sends the document to the client in the destination country. This, together with the B/L should be sent to those responsible for unloading the goods.

- The DUA (Documento único aduanero)

Single customs document (copy) produced on green paper and containing a series of numbered pages on which information on non-EU goods should be entered.

Each sheet has a specific purpose. For example, page three is the copy to be retained by the person sending the document. In this case it is the customs official. With this document the official or the forwarding agent can control the company's turnover and in addition to sending this to the customs officials every year, it must also be sent to Inland Revenue. There are nine pages in total and every page has a different function.

As with the T2L, without this document the goods cannot be unloaded and transported to their destination. Failure to pass through customs (which is necessary for the balance of payment) before unloading goods will be treated as an offence and customs will report the incident to the appropriate authorities and a fine will be imposed. This fine should be paid by whomever responsible for the goods having been loaded without previous clearance. 
Moreover, under normal circumstances the goods are returned to the port of origin. Once they are cleared by customs they can be loaded once again.

\subsection{Transport company's decision making process}

The transport company's decision making process is similar to that of any other intermodaltransportation operator (see Figures 11 and 12).

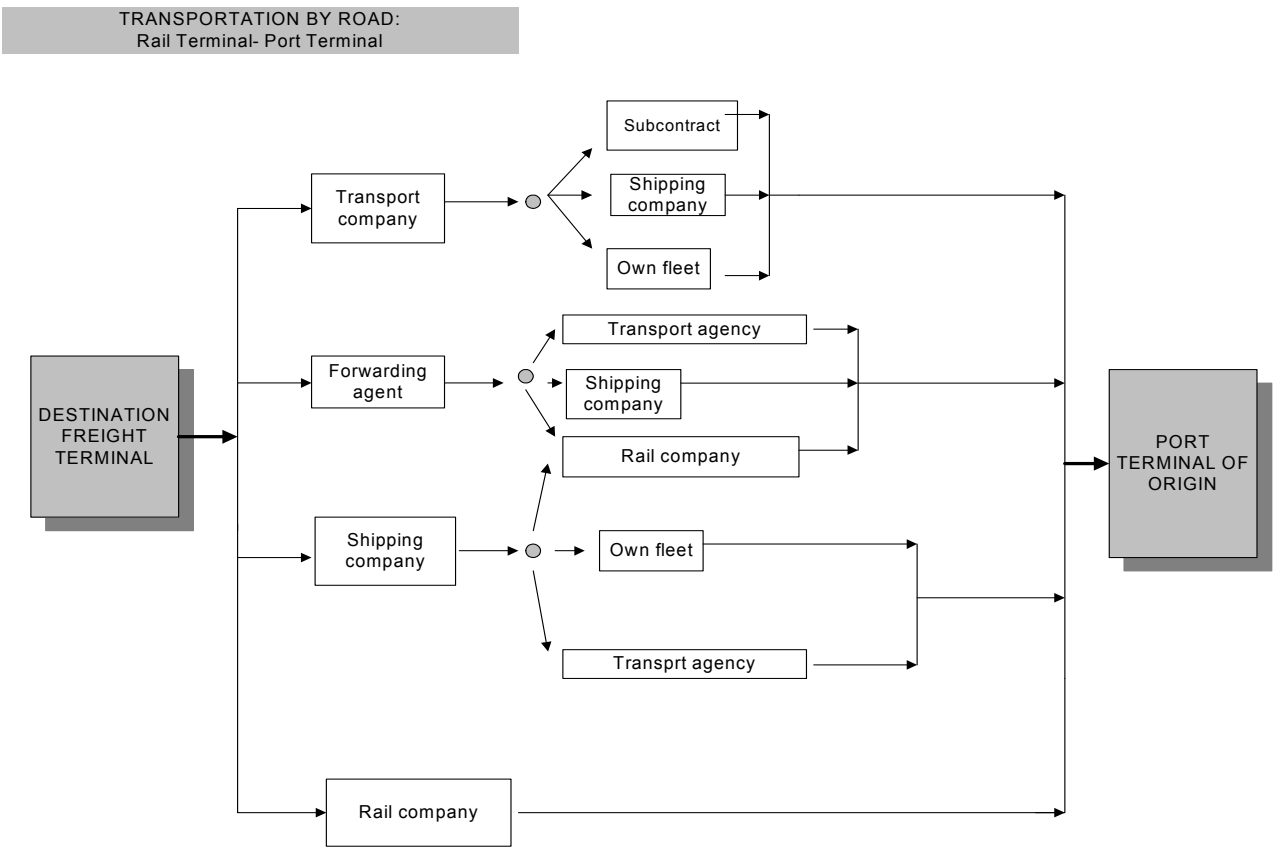

Fig. 11. Transport company's decision making process regarding transportation by land between the rail or port terminal.

The company aims to meet customer demand and considers service quality their number one priority. Enabling factors for ensuring quality service are:

- Regularity.

- Frequency.

- Flexibility.

- Availability.

The transport company offers a wide range of business services, thus providing the client with a better service and maintaining costs as low as possible.

They must take into account the selected route and the transportation modes available. They will then have to study the quotes received from the operators able to participate in the transportation chain. If we assume that we are dealing with the most extensive intermodal transportation chain in which sea, land and rail carriages are included, the operators which may participate are the same as before: the forwarding agent, the rail and shipping company. Each one puts forward a different quotation and the company will decide which one most suits their needs. 


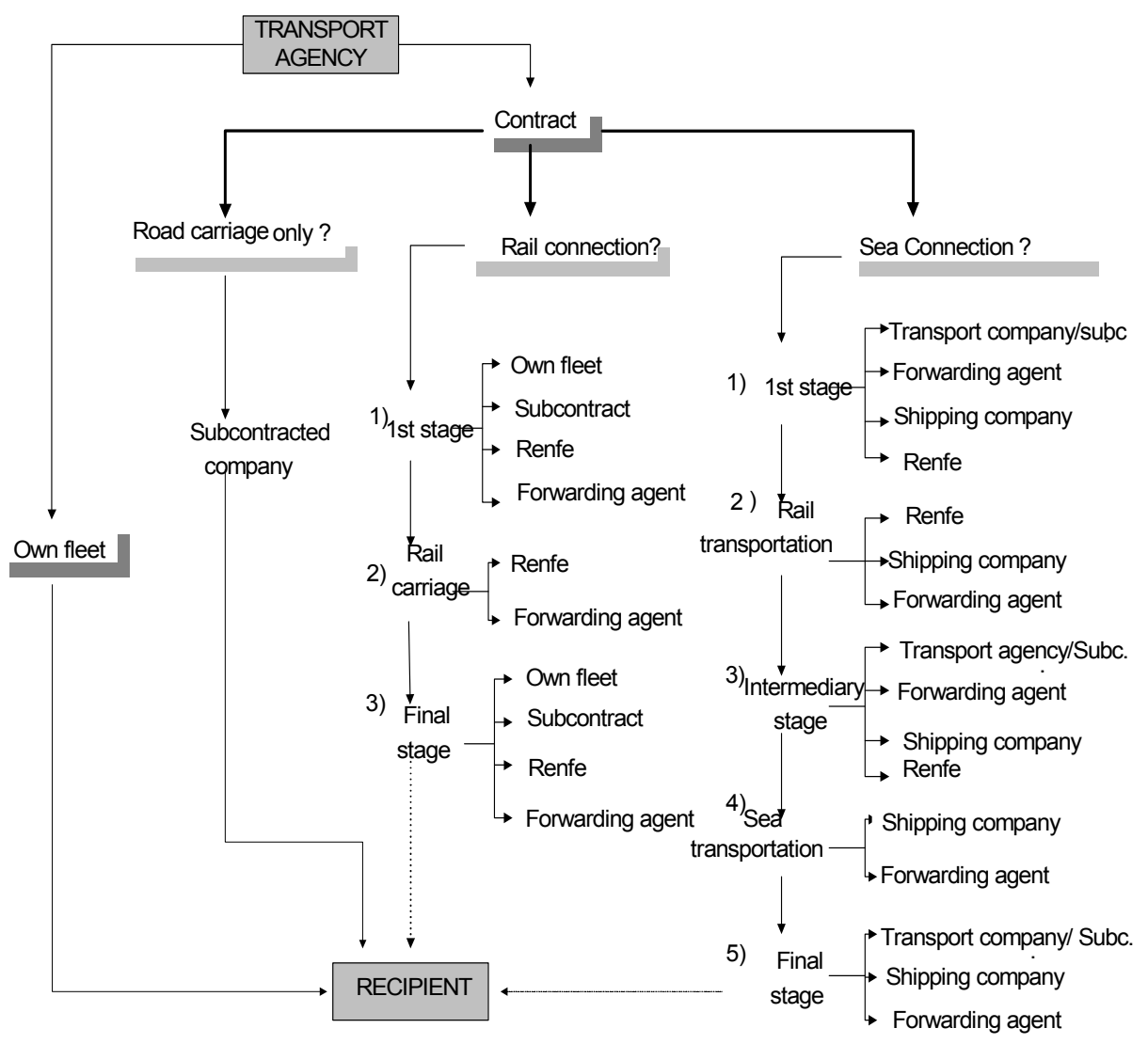

Fig. 12. Transport agency's decision making process within the intermodal transportation chain.

A detailed study of all the quotations is carried out, bearing in mind the following:

- The selected operator(s) is able to comply with the established timetables and schedules, i.e., the frequency of services set out by the company.

- Reliability in terms of continued compliance with schedules, avoiding changes and delays. This is important as interrupting the intermodal chain will incur losses.

- The cost of the service provided and amount saved by choosing one or the other.

Goods may be transported by land using the company's own fleet or by subcontracting the service to another transport company, depending on whichever option is most suitable. If goods need to be transported by sea and/or rail, this may be done by the shipping company or the rail company respectively.

With respect to customs clearance, the companies may take care of this by themselves if they are certified to do so. If this is not the case, they should contact a forwarding agent who can carry out the necessary procedures. 


\section{Case study}

To test our decision-making model, we applied it to a transport company located in Seville, in the south of Spain, managing intermodal shipments from the local port and intermodal rail terminal. The Port of Seville is located 80 kilometres from the mouth of the river Guadalquivir, and is the only commercial inland port that exists in Spain. Its geographical location is perfect for access from both the Mediterranean and Atlantic, with several factors that position it as a first-rate logistical and commercial node. Traffic at the Port of Seville is around five million tonnes annually (Table 1). Regular lines stand out with the Canary Islands for container and ro-ro traffic, which makes the Port of Seville the main maritime gate between the Canaries and the Iberian Peninsula.

\begin{tabular}{|c|c|c|c|}
\cline { 2 - 4 } \multicolumn{1}{c|}{} & $\mathbf{2 0 0 8}$ & $\mathbf{2 0 0 9}$ & $\mathbf{2 0 1 0}$ \\
\hline Goods (Tn) & $4,584,671$ & $4,504,647$ & $4,365,589$ \\
\hline Containers & 130,452 & 129,736 & 152,612 \\
\hline Boats & 1,278 & 1,242 & 1,181 \\
\hline Passengers & 166,990 & 149,646 & 123,025 \\
\hline
\end{tabular}

Table 1. Traffic at the port of Seville.

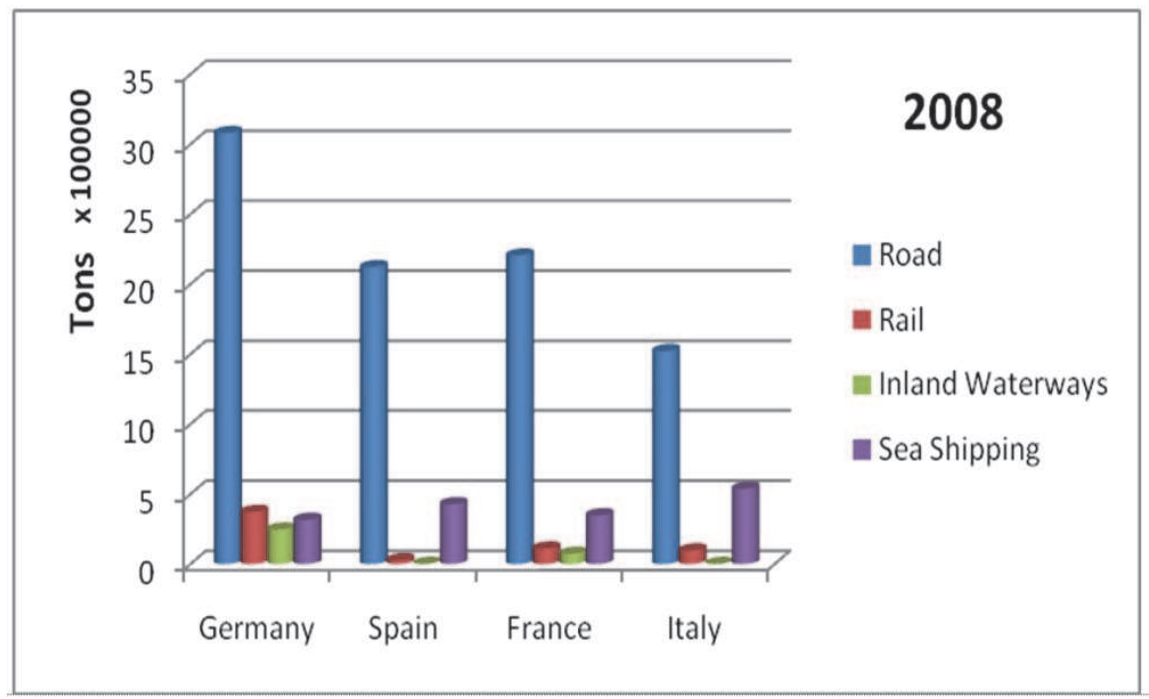

Fig. 13. Movement of freight in Spain, France, Germany and Italy on each transport mode for year 2008.

With respect to rail transport, whereas the total amount of freight moved in Spain is comparable to other European countries, the amount of freight moved by train is significantly lower (see Figure 13 and Figure 14). Specifically, the modal distribution of freight transport in Spain is as follows: road: $82 \%$; water: $12 \%$ (and this mainly due to the shipments to the Spanish islands, with a negligible relevance of short sea shipping); rail: $4 \%$; pipeline: $1.97 \%$; air: $0.03 \%$. Moreover, while the increase in the amount of freight on roads is steady, rail-based transport has shown little or no increments in the recent years. 


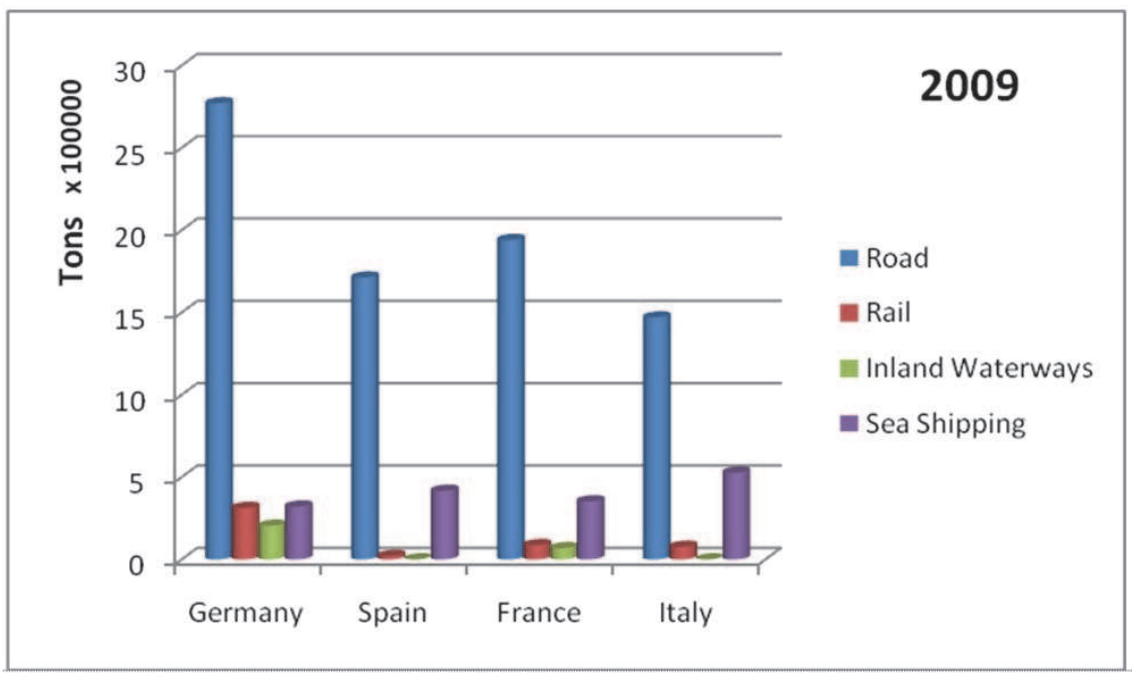

Fig. 14. Movement of freight in Spain, France, Germany and Italy on each transport mode for year 2009.

The only rail operator in Spain is Renfe, the national railway company. Renfe operates a freight division, where other shippers or carriers of general freight may subcontract the delivery of a less-than-wagon load or a whole wagon for a container. The network of freight terminals distributed throughout Spain is depicted in Figure 15.

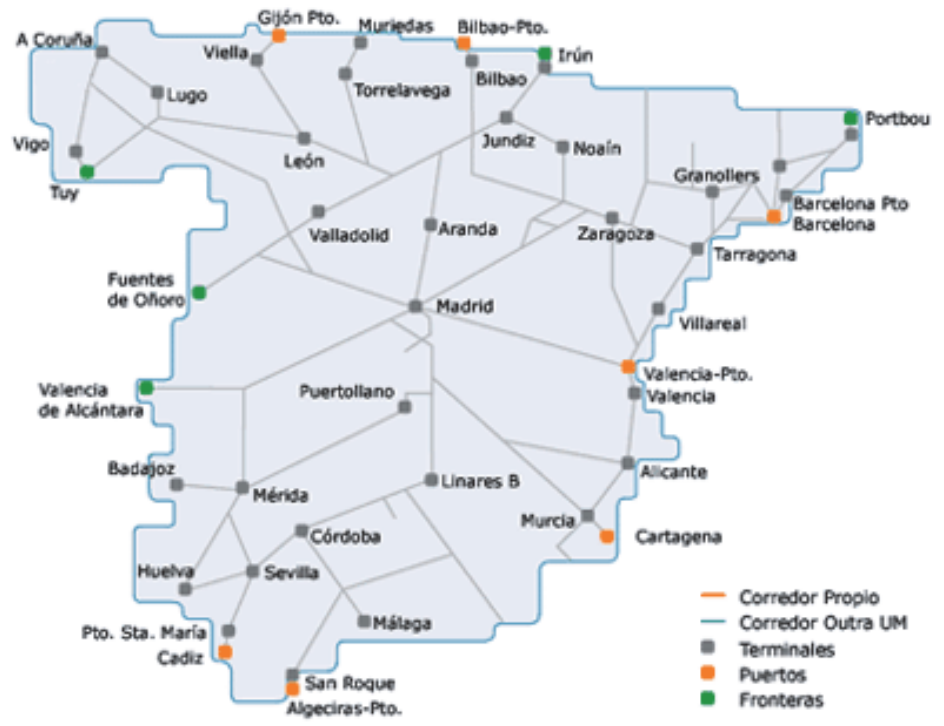

Fig. 15. Freight terminals operated by Renfe in Spain. 
The intermodal shipments run by the company during the two-month period selected for the case study are shown in Tables 2 and 3.

\begin{tabular}{|c|c|c|c|c|c|c|c|c|}
\hline $\begin{array}{c}\text { Distance } \\
\text { (miles) }\end{array}$ & $\begin{array}{c}\text { Time } \\
\text { Taken } \\
\text { (days) }\end{array}$ & $\begin{array}{c}\text { Time } \\
\text { Expected } \\
\text { (days) }\end{array}$ & $\begin{array}{c}\text { Distance } \\
\text { (miles) }\end{array}$ & $\begin{array}{c}\text { Time } \\
\text { Taken } \\
\text { (days) }\end{array}$ & $\begin{array}{c}\text { Time } \\
\text { Expected } \\
\text { (days) }\end{array}$ & $\begin{array}{c}\text { Distance } \\
\text { (miles) }\end{array}$ & $\begin{array}{c}\text { Time } \\
\text { Taken } \\
\text { (days) }\end{array}$ & $\begin{array}{c}\text { Time } \\
\text { Expected } \\
\text { (days) }\end{array}$ \\
\hline 1134 & 21 & 6 & 1504 & 11 & 5 & 540 & 30 & \\
\hline 1134 & 14 & 6 & 1504 & 14 & 5 & 540 & 30 & \\
\hline 1134 & 11 & 6 & 1504 & 14 & 5 & 540 & 17 & \\
\hline 1134 & 10 & 6 & 1504 & 14 & 5 & 540 & 22 & \\
\hline 1134 & 10 & 6 & 1504 & 11 & 5 & 540 & 31 & \\
\hline 1134 & 10 & 6 & 1504 & 9 & 5 & 540 & 18 & \\
\hline 1134 & 14 & 6 & 1504 & 14 & 5 & 540 & 22 & \\
\hline 1134 & 10 & 6 & 1504 & 18 & 5 & 540 & 30 & \\
\hline 1134 & 14 & 6 & 1504 & 14 & 5 & 540 & 30 & \\
\hline 1134 & 11 & 6 & 1504 & 14 & 5 & 540 & 17 & \\
\hline 1134 & 21 & 6 & 1504 & 14 & 5 & 540 & 22 & \\
\hline 1134 & 21 & 6 & 1504 & 14 & 5 & 540 & 31 & \\
\hline 1134 & 11 & 6 & 1504 & 14 & 5 & 540 & 18 & \\
\hline 1134 & 14 & 6 & 1504 & 14 & 5 & 540 & 22 & \\
\hline 1134 & 11 & 6 & 1504 & 14 & 5 & & & \\
\hline 1134 & 9 & 6 & 1504 & 13 & 5 & & & \\
\hline 1134 & 14 & 6 & 1504 & 14 & 5 & & & \\
\hline 1134 & 11 & 6 & 1504 & 11 & 5 & & & \\
\hline 1134 & 13 & 6 & 1504 & 10 & 5 & & & \\
\hline 1134 & 11 & 6 & 1504 & 10 & 5 & & & \\
\hline 1134 & 10 & 6 & 1504 & 10 & 5 & & & \\
\hline 1134 & 10 & 6 & 1504 & 10 & 5 & & & \\
\hline 1134 & 14 & 6 & 1504 & 14 & 5 & & & \\
\hline 1134 & 11 & 6 & 1504 & 18 & 5 & & & \\
\hline 1134 & 11 & 6 & 1504 & 10 & 5 & & & \\
\hline 1134 & 10 & 6 & 1504 & 10 & 5 & & & \\
\hline 1134 & 14 & 6 & 1504 & 10 & 5 & & & \\
\hline 1134 & 15 & 6 & 1504 & 17 & 5 & & & \\
\hline 1134 & 14 & 6 & 1504 & 14 & 5 & & & \\
\hline 1134 & 11 & 6 & 1504 & 10 & 5 & & & \\
\hline 1134 & 14 & 6 & 1504 & 32 & 5 & & & \\
\hline 1134 & 10 & 6 & 1504 & 11 & 5 & & & \\
\hline 1134 & 11 & 6 & 1504 & 14 & 5 & & & \\
\hline 1134 & 14 & 6 & 1504 & 10 & 5 & & & \\
\hline 1134 & 14 & 6 & 1504 & 10 & 5 & & & \\
\hline 1134 & 14 & 6 & & & & & & \\
\hline
\end{tabular}

Table 2. Data on the intermodal waterborne shipments delivered by the case-study company. 


\begin{tabular}{|c|c|c|c|c|c|}
\hline $\begin{array}{c}\text { Distance } \\
(\mathbf{K m})\end{array}$ & $\begin{array}{c}\text { Time } \\
\text { Taken } \\
\text { (days) }\end{array}$ & $\begin{array}{c}\text { Time } \\
\text { Expected } \\
\text { (days) }\end{array}$ & $\begin{array}{c}\text { Distance } \\
\text { (miles) }\end{array}$ & $\begin{array}{c}\text { Time } \\
\text { Taken } \\
\text { (days) }\end{array}$ & $\begin{array}{c}\text { Time } \\
\text { Expected } \\
\text { (days) }\end{array}$ \\
\hline $\mathbf{1 0 9 9}$ & 2 & 1,5 & $\mathbf{5 7 0}$ & 3 & 1 \\
\hline $\mathbf{1 0 9 9}$ & 2 & 1,5 & $\mathbf{5 7 0}$ & 2 & 1 \\
\hline $\mathbf{1 0 9 9}$ & 2 & 1,5 & $\mathbf{5 7 0}$ & 3 & 1 \\
\hline $\mathbf{1 0 9 9}$ & 2 & 1,5 & $\mathbf{5 7 0}$ & 2 & 1 \\
\hline $\mathbf{1 0 9 9}$ & 2 & 1,5 & $\mathbf{5 7 0}$ & 4 & 1 \\
\hline $\mathbf{1 0 9 9}$ & 10 & 1,5 & & & \\
\hline $\mathbf{1 0 9 9}$ & 2 & 1,5 & & & \\
\hline $\mathbf{1 0 9 9}$ & 2 & 1,5 & & & \\
\hline $\mathbf{1 0 9 9}$ & 2 & 1,5 & & & \\
\hline $\mathbf{1 0 9 9}$ & 3 & 1,5 & & & \\
\hline
\end{tabular}

Table 3. Data on the intermodal rail shipments delivered by the case-study company

\subsection{Cost data}

In order to represent the decision-making process of companies involved in intermodal transport, we gathered all the cost-related data for each link of the intermodal chain. This included vehicle cost components, rail and ship tariffs, intermediary supplements, etc. The data collection was carried out by accessing the appropriate statistical sources in each case, or by direct consultation to the involved stakeholders.

\subsubsection{Road transport}

The Spanish Ministry of Public Works publishes a yearly report (Ministerio de Fomento, 2009) for road transport companies providing them with reliable criteria upon which they may establish the price of the service offered. This publication contains average cost data related to the different concepts involved in road transport, and has become a capital reference for the establishment of transport rates in the country. An example of the type of data provided is shown in Table 4 . The cost data was then translated into prices by adding the average commercial margins in the sector.

\subsubsection{Rail transport}

Every year the rail company Renfe offers its clients rates depending on the origin and destination terminal. The rates data for haulages departing from Seville is shown in Table 5. On top of these rates, clients must pay a surcharge for the different additional services (road haulage, container storage, etc.) offered by Renfe.

\subsubsection{Waterborne transport}

The rates charged for the waterborne transport of a container correspond to the transport itself, which is often negotiated between the shipper and the carrier, plus the port charges. The concepts normally included in a vessel transport invoice are: 


\begin{tabular}{|l|r|r|}
\cline { 2 - 3 } \multicolumn{1}{c|}{} & \multicolumn{2}{c|}{ ANNUAL DIRECT COSTS } \\
\cline { 2 - 3 } \multicolumn{1}{c|}{} & \multicolumn{1}{c|}{ Euros } & Distribution (\%) \\
\hline Direct costs & $119,420.84$ & $100.0 \%$ \\
\hline Costs per time & 65,274034 & $54.7 \%$ \\
\hline Vehicle depreciation & 13,844084 & $11.6 \%$ \\
\hline Vehicle financing & $1,302.69$ & $1.1 \%$ \\
\hline Drivers & 28,384073 & $23.8 \%$ \\
\hline Insurance & $6,848.08$ & $5.7 \%$ \\
\hline Tax costs & 928.00 & $0.8 \%$ \\
\hline Expenses & $13,966.00$ & $11.7 \%$ \\
\hline Kilometric costs & $54,146.50$ & $45.3 \%$ \\
\hline Fuel & $41,619.83$ & $34.9 \%$ \\
\hline Tyres & $6,730.67$ & $5.6 \%$ \\
\hline Maintenance & $2,088.00$ & $1.7 \%$ \\
\hline Repairs & $3,708.00$ & $3.1 \%$ \\
\hline Annual distance travelled (km/year) & 120,000 & \\
\hline Annual distance travelled for loaded vehicles (km/year) & 102,000 & \\
\hline Direct Costs (euros/km covered) & 0.995 & \\
\hline Direct Costs (euros/km covered by loaded vehicle) & 1.171 & \\
\hline
\end{tabular}

Table 4. Average cost data for a vehicle containing a normal load $(420 \mathrm{HP}, \mathrm{MAM}=40,000 \mathrm{~kg}$ and payload of $25,000 \mathrm{~kg}$ ). Base hypothesis: $20,000 \mathrm{~km}$ covered every year, $85 \%$ loaded and 15\% empty. (Source: Spanish Ministry of Public Works).

- $\quad$ The haulage rate (BAS) for sea transportation and the previous procedures associated with ship operations.

- Obtaining the necessary currency for payment of freight.

- $\quad$ THC for handling of goods in port terminals. This is called the $\mathrm{OHC}$ in the terminal of origin and $\mathrm{DHC}$ in the terminal of destination.

- The goods rate (PTD) for use of port facilities. This depends on the weight of the goods and the container.

- Management of the consignee (shipping company) for port operations between them and the forwarding agent, the customs official, recipient/shipper, port terminal and carrier. This involves the notification of arrival, the B/L (bill of lading) and the delivery and acceptance order. A sum is paid for the processing of documents. In the origin this is called the ODF and in the destination the DDF.

- Management of the Customs official for goods clearance procedures (presentation of DUA, customs release, closing of DUA, and/or presentation of additional documentation, physical inspection, representation and obtaining of customs release document or physical inspection) which will be explained later.

- $\quad$ IHE Inland Haulage Export (TTE)/Import (TTI).

- Warranty of article 102: warranty to respond as a whole to deferment of payment of the customs debt in accordance with the Customs Code.

- $\quad$ BAF. This is the amount to be paid depending on the cost of fuel.

- $\mathrm{CCN}$ is the surcharge for cleaning the container (this varies according to terminal).

- Occupancy: this is the amount to be paid for temporary storage of goods in the terminal port and for any delays caused as a result of container occupancy. 


\begin{tabular}{|c|c|c|c|c|c|c|c|c|}
\hline \multirow{3}{*}{ DESTINATION } & \multirow{3}{*}{$\mathrm{CH}$} & \multicolumn{4}{|c|}{ LOADED } & \multicolumn{3}{|c|}{ EMPTY } \\
\hline & & $20^{\prime}<12$ & $20^{\prime}>12$ & $\underline{30}$ & $\underline{40}$ & $\underline{20^{\prime}}$ & $\underline{30}$ & $\underline{40^{\prime}}$ \\
\hline & & Tonnes & Tonnes & & & & & \\
\hline A CORUÑA S.D. & * & 404.2 & ב504.21 & 615.29 & 779.75 & 270.02 & 403.05 & 452.37 \\
\hline $\begin{array}{l}\text { BARCELONA } \\
\text { MORROT }\end{array}$ & * & 410.74 & 514.19 & 625.19 & 792.22 & 274.38 & 409.52 & 459.54 \\
\hline BILBAO PORT & * & 376.79 & 477.74 & 558.96 & 703.34 & 262.19 & 377.92 & 423.86 \\
\hline GIJON PORT & * & 370.3 & 467.5 & 577.57 & 686.53 & 263.77 & 378.98 & 428.72 \\
\hline IRUN & * & 368.56 & 452.52 & 560.77 & 710.33 & 246.66 & 367.95 & 412.72 \\
\hline JUNDIZ & * & 340.21 & 439.61 & 517.54 & 655.63 & 227.72 & 339.82 & 381.03 \\
\hline LEON & * & 316.97 & 388.88 & 469.22 & 591 & 229.29 & 328.51 & 375.74 \\
\hline $\begin{array}{c}\text { MADRID } \\
\text { ABROÑIGAL }\end{array}$ & & 178.92 & 224.45 & 272.39 & 344.91 & 119.11 & 177.41 & 199.14 \\
\hline MURIEDAS & * & 340.21 & 439.61 & 517.54 & 655.63 & 227.72 & 339.82 & 381.03 \\
\hline NOAIN & * & 367.19 & 448.1 & 546.68 & 688.36 & 263.39 & 379.43 & 430.92 \\
\hline SILLA & * & 266.53 & 375.62 & 405.32 & 517.54 & 178.24 & 265.54 & 298.12 \\
\hline $\begin{array}{l}\text { TARRAGONA } \\
\text { CONSTANTI }\end{array}$ & * & 383.11 & 479.12 & 582.37 & 738.67 & 280.76 & 382.69 & 429.29 \\
\hline $\begin{array}{c}\text { VALLADOLID } \\
\text { ARGALES }\end{array}$ & * & 238.61 & 299.32 & 356.45 & 452.01 & 177.44 & 245.92 & 275.79 \\
\hline VIGO GUIXAR & * & 380.01 & 473.94 & 578.56 & 733.09 & 254.38 & 379.72 & 426.02 \\
\hline ZARAGOZA & * & 346.42 & 423.33 & 525.11 & 668.36 & 370.74 & 370.74 & 446.86 \\
\hline
\end{tabular}

Table 5. Price rates for containers leaving the Seville intermodal terminal on a Renfe train (CH: Container Hire) (Source: Renfe Combined Transport Rates).

The invoice may have a different layout depending on the shipping company. However, the concepts included are more or less the same as those outlined above. Below we have an example (Table 6) of a Spanish port invoice for a $20^{\prime}$ dry container:

\begin{tabular}{|l|c|}
\hline \multicolumn{2}{|c|}{ Port invoice (euros) } \\
\hline BAS & $400 / 600$ \\
\hline BAF & $30 / 50$ \\
\hline OHC & 140.04 \\
\hline DHC & 140.04 \\
\hline PTD & 30 \\
\hline ODF & 45 \\
\hline DDF & 45 \\
\hline CCN & 6 \\
\hline FFC & 2.5 \\
\hline Carriages & \\
\hline - Internal port & 62 \\
\hline - 0-10km & 100 \\
\hline - over 200 & 1.03 cents $/ \mathrm{km}$ \\
\hline
\end{tabular}

Table 6. Example of a port invoice for a $20^{\prime}$ dry container $(€)$. 
Other concepts are included in the invoice but indirectly. These are the services provided directly or indirectly by each Port Authority.

- Direct Services are those services provided to the ship or goods (in accordance with the BOE, Official Gazette of the Spanish State).

- Indirect Services are those provided to the ship or goods by the Port Authority through individuals or third parties (subcontacted or by means of concession).

We will now look at the different components of this service and their corresponding rates, all of which will be looked at with reference to the Port of Seville.

\subsubsection{Direct services}

- Ships accessing the port, berthing or anchoring:

- The rate is 0.04912 euros/GT for short stays of 3 hours (maximum of 4 periods every 24 hours) Reductions are applicable for the use of facilities under administrative concession, for lack of draught in berthing, mooring method and navigation type (cabotage between ports within the European Union).

- $\quad$ For the number of stopovers made (Table 7):

- For long stays a minimum surcharge of 0.009196 and a maximum of 0.055173 euros per GT and day of stay is applied.

\begin{tabular}{|c|c|}
\hline \multicolumn{2}{|c|}{ Generally Applied Reductions } \\
\hline From 13 to 24 stopovers & $20 \%$ \\
\hline From 25 to 40 stopovers & $45 \%$ \\
\hline From 41 stopovers & $70 \%$ \\
\hline \multicolumn{2}{|c|}{ Reductions for scheduled routes } \\
\hline From 13 to 24 stopovers & $5 \%$ \\
\hline From 25 to 50 stopovers & $15 \%$ \\
\hline From 51 to 100 stopovers & $25 \%$ \\
\hline From 101 stopovers & $35 \%$ \\
\hline
\end{tabular}

Table 7. Applied reductions for the number of stopovers made.

- Goods. Rates for general goods per section (Table 8):

\begin{tabular}{|c|c|c|c|c|}
\hline \multirow{2}{*}{$\begin{array}{c}\text { Discount } \\
\text { group }\end{array}$} & \multirow{2}{*}{ \% disc. * } & \multicolumn{3}{|c|}{ Amount discounted (€/Tonne) } \\
\cline { 3 - 5 } & & UNLD & Base & LD \\
\hline First & 85 & 0.565552 & 0.459774 & 0.354056 \\
\hline Second & 75 & 0.942567 & 0.766290 & 0.590074 \\
\hline Third & 60 & 1.508059 & 1.226065 & 0.944070 \\
\hline Fourth & 30 & 2.639104 & 2.145613 & 1.652122 \\
\hline Fifth & 0 & 3.770149 & 3.065162 & 2.360175 \\
\hline \multicolumn{4}{|c|}{ UNLD=Unloading LD=Loading } \\
\hline
\end{tabular}

Table 8. Rates for general goods per section.

- Other services. Scales:

- For lorry: €1.664804 
- $\quad$ For loaded wagon: $€ 5.709615$

- $\quad$ For empty wagon: $€ 3.305567$

\subsubsection{Indirect services}

Pilotage: Services to facilitate entry to and departure from the port and manpower within the boundaries where such activity takes place. According to National Ports Authority Law, Merchant Navy regulations and the General Regulations of Pilotage, Some of the discounts applicable are:

- For ship type:

- Passenger and Ro-Ro ships: 5\%

- Scheduled Ro-Ro ships: 8\%

- Scheduled Ro-Ro ships which stopped at Seville before 01/06/99 and whose GRT was less than 3000 and GT more than 6000 units: $13 \%$

- Scheduled routes:

- More than 40 annual stopovers: $47 \%$

- More than 24 annual stopovers: $35 \%$

- More than 10 annual stopovers: $20 \%$

- Ships who berth outside the dock: $20 \%$

\section{Results and conclusions}

\subsection{Assessment of the company's operations}

After having applied the decision-making model to the company's intermodal routes, (roadrail-sea and road-rail), the following observations can be made:

- Road-rail-sea-route: Although the decisions taken illustrate how the model may be most effectively implemented, they do not reduce costs. The company is not $100 \%$ efficient, since the initial road carriage is subcontracted. The least expensive option is to contract this through Renfe, provided that they also manage the rail carriage. As our results have shown, contracting Renfe for the road carriage would be less expensive than using the company's own fleet, at least for the first $70 \mathrm{~km}$. Besides, if as a result of the liberalisation of the rail market, Renfe loses its monopoly in this sector, the market will be more competitive and costs will be reduced. In this way, having the rail operator manage the road carriage, as indicated by the model, will be less expensive.

- Road-rail route: The company has been able to optimise the costs incurred in this route by implementing the decision-making model and has therefore made the right decision. The figures show that using intermodal transport, rather than road transport only, considerably reduces costs by $50 \%$, which confirms that intermodal transport is more cost-effective than road for distances greater than $500 \mathrm{~km}$.

Besides, in addition to making its business more economically efficient, the company also aims to maintain customer loyalty and service quality. The introduction of intermodal transport therefore widens the range of services offered to its clients and as new routes open, the incorporation of other services is also possible. As borders are opened up, the company is able to reach other destinations that were previously limited to road transport.

\subsection{General conclusions for intermodal transport in Spain}

Besides using the developed model to assess the specific intermodal operations of the casestudy company, it was also used to analyse transport routes from Seville to the rest of Spain. Depending on the location of intermodal terminals throughout the national territory, and on 
the distances to these terminals and from Seville, it was possible to determine which transport option would be cheapest for hauling a container from Seville to all the other Spanish provinces.

The result is shown in Figure 16, and comes to confirm the generally accepted statement that intermodal transport is only cost-effective for distances longer than $500 \mathrm{~km}$. In the case of Spain, road transport to the East coast would still be the preferred option due to the existence of a highway along the coast, while rail shipments have to pass through Madrid. It is also significant to mention that, even though waterborne transport is only cost-effective for shipments to the islands, it is the second cheapest option, after rail transport, for shipments from Seville to the coastal areas in the north of Spain.

It has been noted that in long distance and intercontinental routes, although the use of intermodal transport improves the relationship between time taken and distance covered, it may also have a negative impact due to periods of unproductivity when goods are stationary and the mode used for the carriage is unavailable. It is therefore necessary to dedicate resources to avoiding any negative impact from factors such as these. For example, this can be done by improving data exchange and compatibility between the different agents' schedules, among others.

Although intermodal transport is much more developed in other countries than in Spain, as time passes and borders are opened up and the market becomes more global, intermodal transport may establish itself as the most efficient solution, thus making it much easier for small and medium enterprises to enter the market.

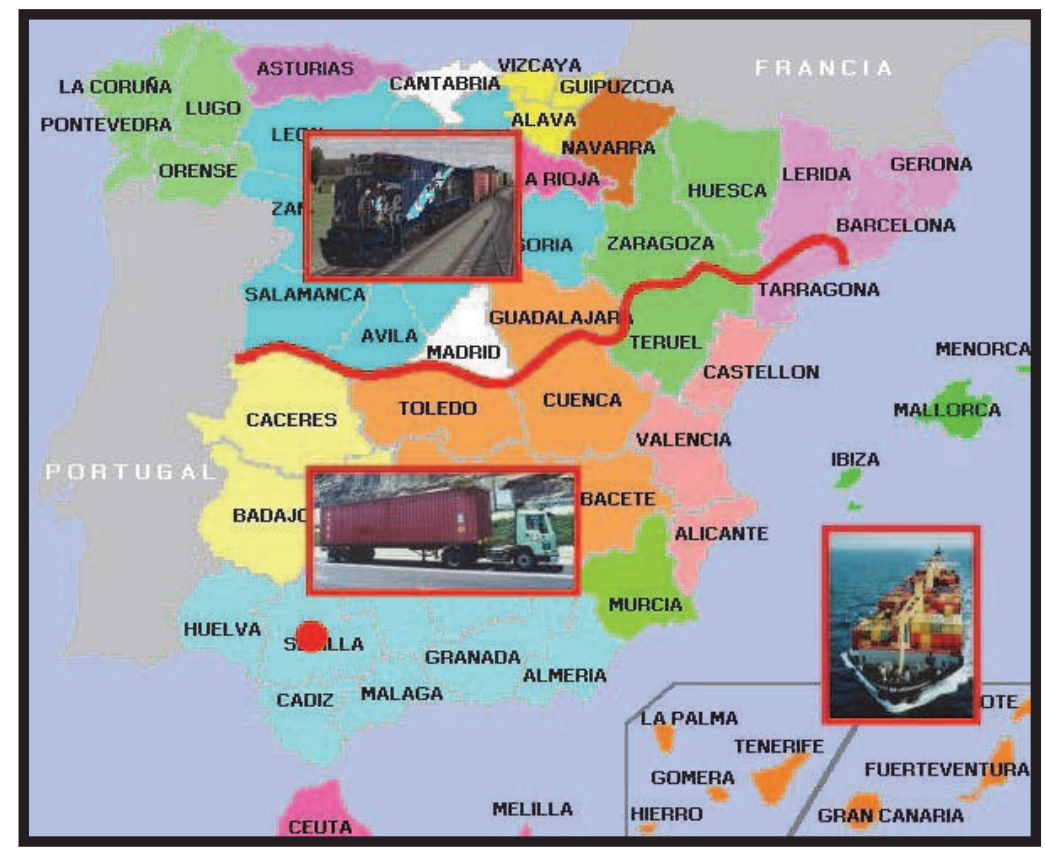

Fig. 16. Cost-effectiveness borders for the different transport modes in Spain for shipments from Seville, as obtained from the decision-making model. 


\subsection{Effect of additional factors}

The analysis was also be extended to other non-monetary effects, such as time and shipment reliability, which play a very important role in making the road more attractive to freight transport than other alternative modes (Modenese Vieira, 1992). One of the objectives of the paper was thus to gain some insight about the importance of these non-monetary effects on the decision-making process related to intermodal transport, as it might sometimes be cheaper than road transport but is also often less reliable. Two additional factors were considered in the analysis:

- $\quad$ The time taken for the delivery, measured as average of time taken. (Table 9 and 10)

- The reliability of the delivery, measured as standard deviation of the time taken. (Table 9 and 10)

\begin{tabular}{|c|c|c|c|}
\hline Distance (miles) & Time Expected (days) & Time average (days) & Standard deviation (days) \\
\hline $\mathbf{1 1 3 4}$ & 6 & 12,72 & 3,09 \\
\hline $\mathbf{1 5 0 4}$ & 5 & 13,24 & 4,07 \\
\hline $\mathbf{5 0 4}$ & & 24,29 & 5,73 \\
\hline
\end{tabular}

Table 9. Data analysis on the intermodal waterborne shipments delivered by the case-study company.

\begin{tabular}{|c|c|c|c|}
\hline Distance $\mathbf{( K m )}$ & Time Expected (days) & Time average (days) & Standard deviation (days) \\
\hline $\mathbf{1 0 9 9}$ & 1,5 & 2,90 & 2,51 \\
\hline $\mathbf{5 7 0}$ & 1 & 2,80 & 0,84 \\
\hline
\end{tabular}

Table 10. Data analysis on the intermodal rail shipments delivered by the case-study company.

The procedure followed consisted in registering data on the intermodal shipments delivered by the case-study company (Table 9 y 10).

In terms of the time taken for deliveries, the high values of the time average of the waterborne case may be explained by the fact that it includes an intercontinental route, and therefore rotations are higher due to port of calls and procedures for entering port areas. As a result, although the distance covered is less than other routes, the time taken is greater. It may also be due to the time taken to load and unload in the port of destination. In the case of rail transport, the time average values are greater than time expected but not as the waterborne case.

In terms of reliability, the data for waterborne transport shows an increased standard deviation with the distance of the trip, international case except for the reasons previously exposed. In the case of rail the trend is the same, which highlights the fact that unexpected delays take place in the distance between origin and destination, and are therefore independent of terminal operations rather than during the movement process itself.

The standard deviation is high. This means that time and reliability vary a lot over the same distance. It would have been useful to look at more routes; however, no more data was available, so the results are not very reliable. However, this type of analysis is useful since it allows us to measure the importance of these additional factors in intermodal transport. With more data, more sophisticated analysis may be carried out and more reliable data obtained. 


\section{References}

Arnold P., Peeters D., \& Thomas I. Modelling a rail/road intermodal transportation system. Transportation Research Part E-Logistics and Transportation Review, Vol. 40, No. 3, (May 2004), pp. 255-270, 1366-5545.

Ballis A., \& Golias J. Towards the improvement of a combined transport chain performance. European Journal of Operational Research, Vol. 152, No. 2, (January 2004), pp. 420-436, 0377-2217.

Barthel F., \& Woxenius J. Developing intermodal transport for small flows over short distances. Transportation Planning And Technolog, Vol. 27, No. 5, (2004), pp. 403-424, 0308-1060.

Cuerda J.C., Fernández M.J., Larrañeta J., Muñoz S., Sánchez F., \& Vélez C. (2003). Environmental policy and environment-oriented technology policy in Spain, In: Environmental and Technology Policy in Europe, Geeerten J.I.S., \& Sedlacek S., pp. 163196, Kluwer Academic Publishers, 1-4020-1583-6, Netherlands.

Dirección General de Programación Económica. (2004). “Encuesta Permanente de Transportes de Mercancías por Carretera (EPTMC)", Ministerio de Fomento.

Li L., \& Tayur S. Medium-term pricing and operations planning in intermodal transportation. Transportation Science, Vol. 39, No. 1, (February 2005), pp. 73-86, 0041-1655.

Macharis C., \& Bontekoning Y.M. Opportunities for OR in intermodal freight transport research: A review. European Journal Of Operational Research, Vol. 153, No. 2, (March 2004), pp. 400-416, 0377-2217.

Ministerio de Fomento. (2006). Observatorio de mercado del transporte de mercancías por carreteras. Centro de Publicaciones, Secretaría General Técnica.

Modenese Vieira L.F. (1992). The value of service in freight transportation. PhD thesis. Massachusetts Institute of Technology.

Observatoire des politiques et des stratégies de transport en Europe. (2005). "Dossier $n^{\circ}$ 7: Le transport intermodal en Europe", Conseil National des Transports (CNT).

Ramstedt L., \& Woxenius J. (2006) Modelling approaches to operational decision-making in freight transport chains. Proceedings of the 18th NOFOMA Conference, Oslo, June 2006.

Walker W.E., van Grol H.J.M., Rahman S.A., Lierens A., \& Horlings E. Improving the intermodal freight transport system linking Western Europe with central and Eastern Europe - Identifying and prioritizing policies. Transportation Research Record, Vol. 1873, (2004), pp. 109-119, 0361-1981. 


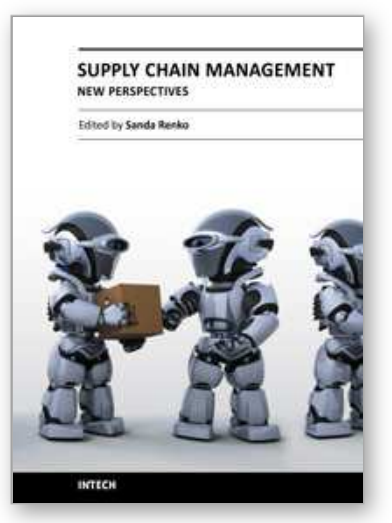

\author{
Supply Chain Management - New Perspectives \\ Edited by Prof. Sanda Renko
}

ISBN 978-953-307-633-1

Hard cover, 770 pages

Publisher InTech

Published online 29, August, 2011

Published in print edition August, 2011

Over the past few decades the rapid spread of information and knowledge, the increasing expectations of customers and stakeholders, intensified competition, and searching for superior performance and low costs at the same time have made supply chain a critical management area. Since supply chain is the network of organizations that are involved in moving materials, documents and information through on their journey from initial suppliers to final customers, it encompasses a number of key flows: physical flow of materials, flows of information, and tangible and intangible resources which enable supply chain members to operate effectively. This book gives an up-to-date view of supply chain, emphasizing current trends and developments in the area of supply chain management.

\title{
How to reference
}

In order to correctly reference this scholarly work, feel free to copy and paste the following:

Jesús Muñuzuri, Rafael Grosso, Pablo Cortés and José Guadix (2011). Development of a Cost Model for Intermodal Transport in Spain, Supply Chain Management - New Perspectives, Prof. Sanda Renko (Ed.), ISBN: 978-953-307-633-1, InTech, Available from: http://www.intechopen.com/books/supply-chainmanagement-new-perspectives/development-of-a-cost-model-for-intermodal-transport-in-spain

\section{INTECH}

open science | open minds

\section{InTech Europe}

University Campus STeP Ri

Slavka Krautzeka 83/A

51000 Rijeka, Croatia

Phone: +385 (51) 770447

Fax: +385 (51) 686166

www.intechopen.com

\section{InTech China}

Unit 405, Office Block, Hotel Equatorial Shanghai

No.65, Yan An Road (West), Shanghai, 200040, China

中国上海市延安西路65号上海国际贵都大饭店办公楼 405 单元

Phone: +86-21-62489820

Fax: +86-21-62489821 
(C) 2011 The Author(s). Licensee IntechOpen. This chapter is distributed under the terms of the Creative Commons Attribution-NonCommercialShareAlike-3.0 License, which permits use, distribution and reproduction for non-commercial purposes, provided the original is properly cited and derivative works building on this content are distributed under the same license. 